\title{
CONFISCATION ON THE ASSETS OF STATE-OWNED ENTERPRISES IN THE PERSPECTIVE OF TAXATION LAW
}

\author{
Zainal Muttaqin \\ Faculty of Law Padjajaran University, Bandung - Indonesia \\ E-mail: zm_fh76@yahoo.com
}

\begin{abstract}
Regime of the State Finance Law as stipulated in Law Number 17 Year 2003 and Law Number 1 Year 2004 which classify separated state finances as State-owned enterprises capital into the definition of state finances, thats why anyone is prohibited from confiscating their assets. The problem is in the case of State-owned enterprises as taxpayers do not pay the tax debt, thus against State-owned enterprises can not be enforced by law in the form of confiscation of his wealth? This paper aims to analyze the above issues based on applicable legal doctrine. From a legal perspective, State-owned enterprises is a separate legal entity from the owner of capital (state). Thus, the capital sourced from the state in the State-owned enterprises is not the property of the state anymore but has become a wealth of state enterprises as legal entities, as well as taxpayers. Thus, Law Number 17 Year 2003 which states state assets separated in State-owned enterprises including state assets, is inconsistent with applicable legal theory, so that Article 50 paragraph (1) of Law Number 1 Year 2004 should not apply to State-owned enterprises.
\end{abstract}

Keywords: state-owned enterprises, confiscated, legal entity, state finance, tax.

\begin{abstract}
Abstrak
Rezim Hukum Keuangan negara yang diatur dalam Undang-Undang Nomor 17 Tahun 2003 dan UndangUndang Nomor 1 Tahun 2004 mengklasifikasikan keuangan negara yang dipisahkan sebagai modal BUMN ke dalam pengertian keuangan negara, sehingga siapa pun dilarang melakukan sita atas aset yang dimilikinya. Persoalannya adalah dalam hal BUMN sebagai wajib pajak tidak melunasi utang pajak, apakah dengan demikian terhadap BUMN tidak dapat dilakukan penegakan hukum berupa sita atas kekayaannya? Tulisan ini bertujuan untuk menganalisis persoalan di atas berdasarkan doktrin hukum yang berlaku. Dari perspektif hukum, BUMN merupakan badan hukum privat yang berdiri sendiri (legal entity) yang terpisah dari pemilik modal (negara). Dengan demikian modal yang bersumber dari negara pada BUMN bukan kekayaan milik negara lagi melainkan sudah menjadi kekayaan BUMN sebagai badan hukum, sekaligus sebagai wajib pajak. Dengan demikian, Undang-Undang Nomor 17 Tahun 2003 yang menyatakan kekayaan negara yang dipisahkan dalam BUMN termasuk kekayaan negara, tidak sesuai dengan teori hukum yang berlaku, sehingga pasal 50 ayat (1) Undang-Undang Nomor 1 Tahun 2004 seharusnya tidak berlaku terhadap BUMN.
\end{abstract}

Kata kunci: badan usaha milik negara, sita, badan hukum, keuangan negara, pajak.

\section{Introduction}

In almost countries, taxes are the most reliable source of revenue, including Indonesia. As evidence, for the 2017 budget, approximately $78 \%$ of National State Budget revenues are sourced from the tax sector. Therefore, it is reasonable for the government to pay attention to taxpayer compliance or compliance in tax payments. ${ }^{1}$ For support the success of tax revenue sector, the law on taxation, especially Law Number 28 Year 2007 concerning General Provisions and Tax Procedures has been completed with various sanctions for taxpayers who do not implement or do not fulfill the obligati-

Kadar Pamuji, “Kebijakan Pengelolaan Pajak Daerah dalam Kerangka Penyelenggaraan Otonomi Daerah (Analisa terhadap Implementasi Wewenang Pengelolaan Pajak Daerah oleh Pemerintah Pusat dan Pemerintah Daerah)”, Jurnal Dinamika Hukum, Vol. 14 No. 3, September 2014, p. 439 
on of taxation, administrative sanctions (fines, interest, and increases), criminal sanctions (imprisonment or confinement and fines), and confiscation till auction and hostage (gijzeling). This sanction applies to all taxpayers, both individual taxpayers and corporate taxpayers. ${ }^{2}$

According to Article 1 number 2 Law of General Provisions and Tax Procedures, the institution in the sense of taxpayer includes also State-Owned Enterprise. State-Owned Enterprises as Taxpayers have the same rights and responsibility as other taxpayer such as filling the Notice Letter correctly and paying off or paying the tax payable. State-Owned Enterprises as Taxpayers, if the tax obligations are not met, for example not paying the tax debt, then on it will be billed, started from warning letters, the issuance of Tax Assessment Letters, Tax Collection Letters until the Letter of Foreclosure Order of taxpayer assets as regulated in Law Number 19 Year 2000 concerning Tax Collection under Force Letter.

The confiscation of State-Owned Enterprises assets as Taxpayers will cause problems considering on the state financial law regime as regulated in Law Number 17 Year 2003, the definition of state finance is very broad, including state assets separated from State-Owned Enterprises. Meanwhile, based on Article 50 Paragraph (1) of Law Number 1 Year 2004 concerning State Treasury, stated anyone is prohibited to seize money, movable or immovable goods owned by the State. Law Number 1 Year 2004 did not provide further explanation as to whom the foreclosure prohibition is intended for and on what debt guarantees this provision applies, so that the question arises whether the Directorate General of Taxes also cannot carry out the seizure of the wealth of State-Owned Enterprises with the authority granted based on Law Number 19 Year 2000.

This paper aims to analyze law enforcement in the field of taxation for Taxpayers of State-Owned Enterprises when not applying for

2 Tri Setiady, "Implikasi Utang Pajak Berdasarkan Undang-Undang Nomor 28 Tahun 2008 tentang Ketentuan Umum dan Tata Cara Perpajakan Terhadap Wajib Pajak", Fiat Justisia Jurnal Ilmu Hukum, Vol. 9 No. 2, April-June 2015, p. 136 tax payments based on Law Number 19 Year 2000 and Law Number 1 Year 2004 which equally a public legal regime. Observing the two laws above, it appears the contradictio determinis between the two laws, so there needs a solution about whether or not the wealth of State-Owned Enterprises as taxpayers seized by the state so that there is legal certainty in law enforcement taxation.

\section{Discussion}

\section{State-Owned Enterprises as Legal Entity}

Law Number 19 Year 2003 concerning State-Owned Enterprises which revokes and subtitutes the Law Number 19 of 1960 concerning State Companies and Law Number 9 Year 1969 concerning Stipulation of Interim Government Regulation Number 1 Year 1960 concerning State Forms of Business into law, recognizing two forms of State-Owned Enterprises namely Public Corporation (Perum) and Limited Company (Persero). No longer known Bureau Company (Perjan).

The difference between Perum and Persero, apart from the nature of its business activities, also from the amount of capital owned by the state invested in the State-Owned Enterprises. State-Owned Enterprises is a form of business in certain fields that generally concern the public interest, in which the role of government in it is relatively large. ${ }^{3}$ In this connection, Persero is more business oriented (for profit), while Perum besides seeking profit also have vision of public service. From the capital aspect, the overall capital of Perum is owned by an undivided state of stocks, while Persero's capital is divided into shares in which the state owns at least $51 \%$.

The state capital deposited into StateOwned Enterprises is sourced from state assets separated from the National State Budget. According to the explanation of Article 4 paragraph (1) of the Law on State-Owned Enterprises, the definition of "separated" is the separa-

Januwianti Atikah, "Kajian Hukum tentang Kepemilikan Modal terhadap Badan Usaha Milik Negara Menjadi Badan Usaha Milik Swasta”, Lex Crimen, Vol. V No. 3, 2016, p. 57 
tion of state assets from National State Budget to be used as state equity participation in State-Owned Enterprises for subsequent development and no more management based on the state budget system but based on healthy company principles. Based on Law Number 19 Year 2003, the state represented by the government as the shareholder in the State-Owned Enterprises shall be conducted by the government (Minister of Finance) which subsequently has the authority to develop and supervise it to the Minister of State-Owned Enterprises based on Government Regulation Number 41 Year 2003.

Referring to Article 35 paragraph (2) and Article 11 of the Law of State-Owned Enterprises, both Perum and Persero are legal entities. The way of establishment and position of the Persero is the same as the Limited Company ${ }^{4}$, both was established by notarial deed and legal entity status since it was registered in the Ministry of Law and Human Rights. Article 11 of the Law on State-Owned Enterprises further stated that Persero apply all the provisions and principles applicable to Limited Liability Companies as regulated in Law Number 1 Year 1995. Therefore, State-Owned Enterprise is a separate legal entity that separated from the owners of capital. State-Owned Enterprises becomes the subject of the law itself apart from the law subject of the capital owner. ${ }^{5}$

Theoretically, State-Owned Enterprises as legal entities have been fulfilled with the possession of wealth separated from members, have their own management, have their own goals and interests. ${ }^{6}$ As a consequence, a Stateowned Enterprise is a legal entity, the capital of a State-Owned Enterprise derived from a state asset shall be an asset or property of a

4 Herlien Budiono, “Arah Pengaturan Undang-Undang Nomor 40 Tahun 2007 tentang Perseroan Terbatas Dalam Menghadapi Era Global”, Jurnal Rechtvinding, Vol. 1 No. 2, August 2012, p. 188.

5 Ridwan Khairandy, "Korupsi di Badan Usaha Milik Negara Khususnya Perusahaan Perseroan: Suatu Kajian Atas Makna Kekayaan Negara yang Dipisahkan dan Keuangan Negara", Jurnal Hukum, Vol. 16 No.1, January 2009, p. 88.

6 Inda Rahadiyan, "Kedudukan BUMN Persero sebagai Separate Legal Entity dalam Kaitannya dengan Pemisahan Keuangan Negara pada Permodalan BUMN", Jurnal Hukum lus Quia lustum, Vol. 20 No.4 October 2013, p. 624.
State-Owned Enterprise as a legal entity, not a state property anymore. In this case, according to Arifin Soeriaatmadja, there has been a transformation of ownership law from the state to State-Owned Enterprises as a private legal entity. ${ }^{7}$ As a result, the state's financial status or public money is cut off and converted into private property. The state as the capital owner no longer as a public legal entity, but as a private legal entity.

\section{Wealth of State-Owned Enterprises versus State Property}

The debate on the definition and scope of state finance has occurred prior to the establishment of Law Number 17 Year 2003, when the Indische Comptabiliteits Wet (ICW) is still governed by Ord. 1925 No. 448 and Indische Bedrijven Wet, Ord. 1927 No. 445. The first view, interpreting state finances in a narrow sense, namely limited to finances within the scope of the State Budget, as proposed by Wirjono Prodjodikoro, Aaron Al Rasid, and Arifin Soeriaatmadja. ${ }^{8}$ Meanwhile, according to the second view, state finances are not only State Budget and Income but also include Budgets and Regional Expenditures and state finances that are in state enterprises. This view is represented by Hamid S. Attamimi and Padmo Wahyono. ${ }^{9}$ The replacement of ICW with Law Number 17 Year 2003 did not resolve the issue of the debated substance above, especially among legal practitioners when in contact with corruption acts committed by the State-Owned Enterprises Board of Directors as a result of his actions that harm the company.

In the state finance law regime, regulated in Law Number 17 Year 2003, Law Number 1 Year 2004, and Law Number 15 Year 2004, state finances are given a broad understanding, not only National/Regional State Budget but including state or regions assets managed by

\footnotetext{
Ridwan Khairandy, "Karakter Hukum Perusahaan Perseroan dan Status Hukum Kekayaan yang Dimilikinya", Jurnal Hukum lus Quia lustum, Vol. 20 No.1, Januari 2013, p. 97.

8 Lihat Jimly Asshiddiqie. 2007. Pokok-Pokok Hukum Tata Negara Di Indonesia Pasca Reformasi. Jakarta: Bhuana Ilmu Populer, p. 815.

9 Loc.cit.
} 
other parties in the form of money, securities, accounts receivable, goods and other rights which can be valued with money, including property that is separated from state or regional companies (Article 1 Number 1 jo Article 2 of Law Number 17 Year 2003).

Based on the state finance definition above, the question arises in the event of a debt receivable between a State-Owned Enterprise and a third party. The question is whether the receivables of State-Owned Enterprise include state receivables. Similarly is the debt of State-Owned Enterprise also a state debt? As a consequence of the definition of the state finances above, it will mean the debt or account receivables of State-Owned Enterprise are including debts or state receivables. Is that so?

In this case, there is a Decision of the Constitutional Court Number 77/PUU-IX/2011 dated February $1^{\text {st }}, 2012$, when conducting a judicial review of Law No. 49 Year 1960 concerning State Receivables Management Committee, referring to Article 1 Number 6 of Law Number 1 Year 2004 concerning State Treasury, the Constitutional Court stated that account receivables are only a amount of money that must be paid to the Central/Local Government. Therefore, excluding the accounts receivable by a business entity which is directly or indirectly controlled by the state, in this case, including a State-owned company's receivable bank, so the account receivable of State-Owned Enterprise is excluded in the category of state receivable and consequently, the State Receivables Committee has no authority to manage the State Owned Enterprises Accounts Receivable Agency. In accordance with Law Number 1 Year 2004, the state account receivable is the right of state or government not State-Owned Enterprise as legal entity, independent legal entity. The principle of the separated state property, in this case used as capital participation in State-Owned Enterprise, is the release of property altogether from its parent, ${ }^{10}$ namely the state as the founder make

10 Selatieli Zendrato, Bismar Nasution, Sunarmi, Faisal Akbar Nasution, "Analisis Hukum Atas Pemeriksaan Kekayaan Negara Pada Badan Usaha Milik Negara (BUMN) the State-Owned Enterprises assets as a legal entity.

The polemic on the assets of the StateOwned Enterprises was responded by the Supreme Court in a fatwa Number WKMA/Yud/ 20/VIII/2006 dated August 16, 2006 explaining that the management of separated state assets especially in State-Owned Enterprises excludes untied state finances to state financial provisions. Contradiction between Law Number 17 Year 2003, Law Number 1 Year 2004, with the Law of State-Owned Enterprise and Limited Liability Company Law can not be resolved by the Constitutional Court Decision because there are other laws that still include State-Owned Enterprise assets as legal entities into state assets such as Law Number 20 Year 2001 concerning Corruption and Law Number 15 Year 2006 concerning the Supreme Audit Board. This issue needs further study beyond this discussion.

\section{Tax Foreclosure Based on Law Number 19 Year 2000}

As explained previously, in the tax law, Stated-Owned Enterprises either Perum or Persero included in the category of taxpayers. Stated-Owned Enterprises as taxpayers have the same rights and obligations as other taxpayers, including sanctions that may be imposed if Taxpayers of State-Owned Enterprise does not perform its obligations. One of the tax sanctions that is a problem is the seizure based on Law Number 19 Year 2000 on the wealth or assets of State-Owned Enterprise in connection with the provision of Article 50 paragraph (1) of Law Number 1 Year 2004 which prohibits anyone to seize the state's wealth. Is Law Number 19 Year 2000 not applicable or unenforceable to Tax payers of State-Owned Enterprise due to Article 50 paragraph (1) of Law Number 1 Year 2004 ?

Law Number 19 Year 2000 does not provide exceptions of confiscation against Tax payers, which is known as an exception to confis-

Mengenai Putusan Mahkamah Konstitusi Nomor 48 Dan 62/PUU-XI/2013", USU Law Journal, Vol. 4 No. 2, March 2016, p. 111 
cation object. Basically, all Tax payers movable and immovable property can be confiscated as collateral for the settlement of its tax debt to the state. This is in accordance with the principle of accounts payable under Article 1131 of the Civil Law (Civil Code).

According to Article 15 paragraph (1) of Law Number 19 Year 2000, there are exempt assets from seizure, namely:

a. Clothes and bedding and equipment;

b. Food and beverage supplies for one month;

c. Supplies of the Taxpayer who are of service obtained from the state;

d. Books relating to the job or occupation of the Tax Payer and the tools used for education, culture and scholarship;

e. Equipment in a state of road that is still used to carry out work or daily business with a total amount not more than Rp. 20,000,000.00 (twenty million rupiah);

f. Disability equipment used by the Tax Payer and the dependent family.

Therefore, beside the assets referred in Article 15 paragraph (1) above, the wealth of Tax payers including State-Owned Enterprises may be confiscated as collateral for the settlement of tax debt. In case the Taxpayers property has been confiscated by the District Court or another agency, the tax bomber submits a Force Letter (seizure) to the court with the aim that in the event of an auction, the state gets priority tax payment as a form of the right of priority of the state ${ }^{11}$, as a form of equal treatment among all taxpayers.

This view is acceptable on the premise that State-Owned Enterprises are independent legal subjects separate from the state as the owner of capital. In addition, Law Number 19 Year 2000 does not provide for the exemption of confiscation of certain Taxpayers. Therefore, it can be understood also the views of the Supreme Court in the National Congress in 2010

11 Risa Nur Istiyah, Ratih Nur Pratiwi, dan Stefanus Pani Rengu, "Efektivitas Penyitaan Harta Kekayaan Milik Wajib Pajak Badan dalam Rangka Mengurangi Tunggakan Wajib Pajak (Studi pada Kantor Pelayanan Pajak Pratama Malang Utara)", Jurnal Administrasi Publik (JAP), Vol. 2. No. 3, 2014, p. 452-457 which argues that the state finance that included the participation of capital (inbreng) in State-Owned Enterprises Limited Persero can be confiscated, because it does not belong to the state anymore but has become the property of Stated-Owned Enterprises. The State-Owned Enterprise's State-Owned Enterprises are subject to Law Number 40 Year 2007 regarding Limited Liability Companies, whereas money or state-owned goods which are not equity participation but managed by State-Owned Enterprises can not be seized in accordance with Article 50 paragraph (1) Law Number 1 Year 2004.

Based on the opinion of the Supreme Court above can be observed several things: first, the Supreme Court recognizes that StateOwned Enterprises is a legal entity separate from the state. Secondly, as a consequence, the wealth of the state that is made into equity, not the wealth of the country anymore. Third, the prohibition of seizure in Article 50 paragraph (1) of Law Number 1 Year 2004 does not apply to capital and assets of State Owned Enterprises.

State assets managed by State-Owned Enterprises which are not or not include capital participation subject to the state financial regime, so Article 50 paragraph (1) of Law Number 1 Year 2004. The prohibition of confiscation of state assets as regulated in Article 50 paragraph (1) Law Number 1 Year 2004 is aimed only at state property which is owned by the state, whether it is self-administered for governance, controlled or used by a third party. In the case of a lawsuit for seizing Surabaya City Government asset, a judicial review of Article 50 Paragraph (1) of Law Number 1 Year 2004, the Constitutional Court in Decision Number 46/PUU-VI/2008 and Decision Number 25/PUU$\mathrm{VII} / 2009$ rejected the lawsuit against Article 50 paragraph (1) and stated that the Surabaya City Government assets are state assets that cannot be seized.

Based on the Decision of the Constitutional Court Number 46/PUU-VI/2008, Decision Number 25/PUU-VII/2009, and Decision Number $77 / P U U-I X / 2011$ can be concluded that there is a separation between the State and State-Own- 
ed Enterprises as legal entities, as well as his wealth status. Therefore, State-Owned Enterprises in arrears or non-paying taxes may be confiscated of their assets, either in the form of State-Owned Enterprises Capital or assets derived from the State-Owned Enterprises profit, as the taxes repayment collateral.

\section{Conclusion}

Based on the tax laws, State-Owned Enterprises are the same taxpayers as firms, limited liability companies, cooperatives, and so on. Therefore, State-Owned Enterprises have the same taxation rights and obligations as other taxpayers. Similarly, in the case of StateOwned Enterprises delinquent or non-payment of tax debt, the same law enforcement shall be carried out, such as confiscation of State-Owned Enterprises assets or property. The status of State-Owned Enterprises as a legal entity separate from the state has capital consequences derived from state assets which are separated into the assets of State-Owned Enterprises. Based on the theory of legal entities and some decisions of the Supreme Court, the assets of State-Owned Enterprises, including capital derived from state assets can be confiscated for tax settlement. Article 50 Paragraph (1) of Law Number 1 Year 2004 which contains the prohibition of confiscation of state assets can not be applied to the assets of State-Owned Enterprises.

\section{References}

Asshiddiqie, Jimly. 2007. Pokok-Pokok Hukum Tata Negara Di Indonesia Pasca Reformasi. Jakarta: Bhuana IImu Populer;

Atikah, Januwianti. "Kajian Hukum Tentang Kepemilikan Modal Terhadap Badan Usaha Milik Negara Menjadi Badan Usaha Milik Swasta". Lex Crimen. Vol. V No. 3. 2016. Pp. 57-65;

Budiono, Herlien. "Arah Pengaturan UndangUndang Nomor 40 Tahun 2007 Tentang Perseroan Terbatas Dalam Menghadapi Era Global". Jurnal Rechtvinding. Vol. 1 No.2. August 2012. Pp. 187-198;

Istiyah, Risa Nur. Ratih Nur Pratiwi and Stefanus Pani Rengu. "Efektivitas Penyitaan
Harta Kekayaan Milik Wajib Pajak Badan dalam Rangka Mengurangi Tunggakan Wajib Pajak (Studi pada Kantor Pelayanan Pajak Pratama Malang Utara)". Jurnal Administrasi Publik (JAP). Vol. 2 No. 3. 2014. Pp. 452-457;

Khairandy, Ridwan. "Korupsi di Badan Usaha Milik Negara Khususnya Perusahaan Perseroan: Suatu Kajian atas Makna Kekayaan Negara yang Dipisahkan dan Keuangan Negara". Jurnal Hukum. Vol. 16 No. 1. January 2009. Pp. 73-87. doi: 10.20885/ iustum.vol16.iss1.art5;

, "Karakter Hukum Perusahaan Perseroan dan Status Hukum Kekayaan yang Dimilikinya". Jurnal Hukum lus Quia lustum. Vol. 20 No.1. January 2013. Pp. 81-97. DOI:10.20885/iustum.vol20. iss1.art5;

Pamuji, Kadar. "Kebijakan Pengelolaan Pajak Daerah dalam Kerangka Penyelenggaraan Otonomi Daerah (Analisa terhadap Implementasi Wewenang Pengelolaan Pajak Daerah oleh Pemerintah Pusat dan Pemerintah Daerah)". Jurnal Dinamika Hukum. Vol 14 No. 3. September 2014. Pp. 430-444. doi:10.20884/1.jdh.2014. 14.3. 309 ;

Rahadiyan, Inda. "Kedudukan BUMN Persero sebagai Separate Legal Entity dalam Kaitannya dengan Pemisahan Keuangan Negara pada Permodalan BUMN". Jurnal Hukum lus Quia lustum. No. 4 Vol. 20 October 2013. Pp. 624-640. DOI: 10. 20885/iustum.vol20.iss4.art7;

Setiady, Tri. "Implikasi Utang Pajak Berdasarkan Undang-Undang Nomor 28 Tahun 2008 Tentang Ketentuan Umum Dan Tata Cara Perpajakan Terhadap Wajib Pajak". Fiat Justisia Jurnal Ilmu Hukum. Vol. 9 No. 2. April-June 2015. Pp. 133-150. doi: 10.25041/Fiatjustisia.V9 no2.593;

Tunas, Derlina Sutria. "Efektivitas Penagihan Tunggakan Pajak dengan Menggunakan Surat Paksa pada Kantor Pelayanan Pajak Pratama Manado". Jurnal EMBA. Vol. 1 No. 4. December 2013. Pp. 1520-1531;

Zendrato, Selatieli. Bismar Nasution. Sunarmi. danFaisal Akbar Nasution. "Analisis Hukum atas Pemeriksaan Kekayaan Negara pada Badan Usaha Milik Negara (BUMN) Mengenai Putusan Mahkamah Konstitusi Nomor 48 Dan 62/PUU-XI/2013". USU Law Journal. Vol. 4 No. 2. March 2016. Pp. 109-118; 